\title{
Kosovo's Public Administration Reform in the Context of the European Union Membership Process
}

\author{
Lorentina Mijalica
}

\begin{abstract}
Kosovo, being one of the youngest countries of the world that has come out of a violent war, has to proven itself in the eyes of international community and especially in the eyes of European Union that is able to overcome the challenges that have blocked the path of being politically, economically and socially functional. The first level to overcome these challenges is by having a better public administration, that's why for more than a decade Kosovo is under the process of reforming and modernizing its public administration. Nevertheless the reforming process it seems not to be as successful as it was planned but which are the factors that are blocking the implementation and proper functionality of these reforms? Mostly, political influence is considered to be the main factor in the stagnation of Kosovo's public administration reform process.

The main objective of this paper is to give a historical and detailed background of Kosovo's public administration reform process under the supervision and the pressure of European Union membership aspirations.
\end{abstract}

Keywords-Kosovo, Public Administration, Reform, European Union, Progress.

\section{INTRODUCTION}

Post-war transition process of Kosovo was characterized with international community's assistance, financial and humanitarian support to re-build Kosovo not only economically by also politically and socially, and it seems that the building process had a lot of flaws because still today Kosovo, as a sovereign state, faces considerable challenges in the field of politics and economy. Public administration reform as a process which officially started in 2007 still continues and is challenged by political influence and by the unprofessionalism of its own staff even after years of training programs and schools.

Public administration during the years has been defined in numerous forms. Some of the various definitions which have been offered for the term are: "a detailed and systematic execution of public law"; "the action part of government"; "the activities of the executive branches of national, state and local governments"; "the process of carrying out the public will as expressed in law, the coordination of collective efforts to implement public policy". In other words, the definition of

Lorentina Mijalica is with the "Gazi University" Social Sciences Institute Department of Political Science and Public Administration, Ankara/Turkey public administration deals with the determination and execution of implementation of governmental policies in order to provide the needs for the public/people/citizen.

\section{THE RECONSTRUCTION PROCESS OF KOSOVO’S PUBLIC ADMINISTRATION}

Due to a combination of neglect, war damage and the departure of trained staff the public service structures of Kosovo had been largely inoperative, municipalities were functioning inadequately or not at all. The reconstruction of public administration in Kosovo has passed through three major phases: the establishment of the Interim Administration of the United Nations (UN), the foundation of the Provisional Institutions of Self Government (PISG) and the launch of Kosovo Standards Implementation Plan.

On 12 July 1999, under "Resolution 1244" which was adopted on 10 June 1999 by Security Council, the United Nations Interim Administration Mission in Kosovo was established under the leadership and direction of Special Representative of Secretary-General Bernard Kouchner. UNMIK's task in Kosovo's recovery was composed by four pillars:

- Pillar I: Humanitarian Assistance, led by the Office of the United Nations High Commissioner for Refugees (UNHCR);

- Pillar II: Civil Administration, under the United Nations;

- Pillar III: Democratization and Institution Building, led by the Organization for Security and Co-operation in Europe (OSCE), and

- Pillar IV: Reconstruction and Economic Development, managed by the European Union (EU).

With the aim of the development of a multi-ethnic, nonpoliticized and efficient civil service for Kosovo, in May 2000 UNMIK established the Joint Interim Administrative Structures (JIAS) which later were replaced by the Provisional Institutions of Self-Government. The provisional instruments of JIAS provided fair and effective means for the people of Kosovo to participate in the administrative decisions and processes that affect every aspect of their daily life. JIAS created twenty (20) Administrative Departments (akin to ministries) responsible for activities across sectors such as health, education, social welfare, public services, 
reconstruction etc. In consultation with local political parties, the new local structures such as the municipal council and the administrative board were formed on 25 February 2000.

First of the consultative bodies of JIAS were the Interim Administrative Council (IAC) and the Kosovo Transitional Council (KTC). A key project envisaged by the institutionbuilding pillar in the field of public administration training was the establishment of the Institute for Civil Administration. This institute was the official training institution for the public sector.

\section{Kosovo’s PUblic AdMINISTRATION REFORM PROCESS}

An interesting perception among the civil service servants during the administration of UNMIK was that their career depends on political allegiance more than on professional skills, leading them to apply for positions in bodies where they believe that they would not be perceived as political opponents by the leadership. This has led to an alignment of civil servants according to party politics, in contravention of the principles of merit, political neutrality, and impartiality.

The Joint Interim Administrative Structures (JIAS) were replaced by the Provisional Institutions of Self-Government on 15 May 2001. The Provisional Institutions of Self-Government were Assembly; President of Kosovo; Government; Courts; and Other Bodies and Institutions. The process of the transferring responsibilities from UNMIK to Provisional Institutions had taken two forms: first, the transfer of political authority to take relevant decisions, which was immediate, and second, the transfer of executive functions from international staff to Kosovo civil servants, which was incremental. The Transfer Council was established by UNMIK and the Provisional Institutions to oversee, coordinate and manage the transfer process.

In order to reduce the possibility of undue political pressure and to raise the chance of professional considerations and civic responsibility to take primacy the Kosovo Institute for Public Administration was established in 2003 and was responsible for the overall training of civil servants of Kosovo Civil Service. The civil service created by UNMIK and the PISG had to take into account the principles of equity, political neutrality and impartiality, integrity, honesty and accountability, transparency, merit, non-discrimination, and inclusiveness.

The launch of the Kosovo Standards Implementation Plan on 31 March 2004 which is considered as the third major step of Kosovo's public administration building process was related to the "Standards for Kosovo" document and the determination of Kosovo's future status. The "Standards for Kosovo" document set out in clear and detailed terms the standards that Kosovo must achieve in order to be taken seriously for future status discussions. Security Council decided, on 24 October 2005 to launch a political process designed to determine Kosovo's future status as foreseen in Security Council resolution 1244 (1999). On 10 November, the Security Council endorsed the appointment of Martti Ahtisaari as
Secretary General's Special Envoy for the future status process. Secretary General's Special Envoy Mr. Ahtisaati on 2 February 2006 submitted a draft comprehensive proposal for the Kosovo status settlement ("Settlement Proposal") to Kosovo and Serbia's representatives. The elements that Kosovo's independence was dependent on and comprise the twelve annexes of the "Settlement Proposal" were: Kosovo's Governance; Rights of communities; Decentralization; Justice System; Protection and promotion of religious and cultural heritage; Returns/protection of property; Economy; Security; Future international presence; International Civilian Representative; European Security and Defense Policy Mission; International Military Presence; and Organization for Security and Cooperation in Europe mission in Kosovo. On 17 February 2008, the Assembly of Kosovo held a session during which it adopted a declaration of independence in which it declared Kosovo an independent and sovereign State.

As envisaged in the settlement proposal, the leading role in the future international presence in Kosovo was going to be carried out by the European Union. European Union Rule of Law Mission (EULEX), became operational in December 2008. During this time Kosovo's future was directed more toward European Integration. European Agency for Reconstruction, Community Assistance for Reconstruction, Development and Stabilization (CARDS) and European Partnership for Kosovo were the reconstruction and guiding system toward European Standards and Law compatibility.

From the time of the establishment, institutions of Kosovo lacked functionality, transparency, and productivity and anticorruption strategy, Law on Anti-Corruption, Anti-Corruption Council were adopted and established by without visible progress. On 24 March 2007, the Kosovo Government adopted the "Strategy for Public Administration Reform in Kosovo 2007-2012" together with "Action Plan for Reform of Public Administration 2009-2012" for its implementation. Main objectives of the Strategy were: professional and depoliticized public administration; structure and organization of effective horizontal and vertical institutions; quality, transparent and effective management and responsive in setting and realizing goals; effective mutual communication with citizens; e-governance; functional and effective system of planning, management and supervision of costs in PA; promotion of development and harmonization of policies and legislation in harmony.

In April 2008 the Government of Kosovo began a major program FRIDOM - Functional Review and Institutional Design of Ministries (2008-2010) for functional review of all ministries. On December 2008 the "Strategy of Electronic Government 2009-2015" was adopted by Government of Kosovo for a more modern, effective, efficient public administration which is in step with European and global technological development trends.

After the proposed reforms by FRIDOM project the "Strategy for Public Administration Reform (2007-2013)" had gone through the revision process. The revised "Public 
Administration Reform Strategy (2010-2013)" contained twelve objectives such as policy management; drafting of legislation; ethics and transparency; communication and participation of citizens; budget planning; budget execution; internal control and audit; public procurement; reorganization of public administration; management and development of human recourses; rationalization of administrative processes; and e-government. The strategy was a guideline for Kosovo Government's vision fulfillment for a public administration: a) Effective in the delivery of administrative services; b) Efficient from the point of view of the costs; and c) European in its organization and working methods. The "Action Plan 20122014" was adopted for the implantation process of the strategy.

In September 2015, the "Strategy on Modernization of Public Administration 2015-2020" and "Action Plan 20152017" were adopted. Three main objectives pointed out in the strategy are:

- An advanced and adequate system for management, monitoring and implementation of legislation on civil service and creating the possibility for a professional, effective and efficient civil service which will be developed based on principles of good administration and oriented towards implementation of legal requirements;

- Qualitative and accessible public administrative services, based on reasonable administrative procedures and applying egovernment methods oriented towards citizen and business needs; and

- Transparent, accountable public administration, with a clear system of accountability, characterized with a professional civil service, with internal administrative structures that function based on the legislation on public administration and in line with principles of good governance.

The main problems identified in the strategic development process during the two earlier cycles of PAR policies are specified as the broad and dispersed scope of PAR Strategy; the lack of clear prioritization between objectives; action plans overloaded with certain activities irrelevant for the time; performance monitoring focused on the process, not results; and failure to set separate budget codes for activities based on the Action Plan.

By the end of 2015, the Strategy for Training of Civil Servants 2016-2020 was approved by the Government. The Strategy aimed to improve the existing framework for civil servants set by previous training strategy (2011-2013). The Strategy for Training of Civil Servants aimed to raise the level of professionalism in the civil service; raising the level of general and specific knowledge needed for the integration of Kosovo in European Union; increasing the level of administrative services that meet the citizens' needs; increasing the level of use of modern information technology in the daily work of civil servants; and centralization of financial resources for the implementation of the Strategy. "Plan of Action for Three Year Period 2016-2018 for Implementation of the Strategy on Training of Civil Servants
2016-2020" was approved by the Government by the end of 2015.

\section{CONCLUSION}

The progress made in the field of public administration reform is evaluated by the annual European Commissions progress reports for Kosovo, SIGMA's annual assessment and priorities reports, and the Government Annual Work Plans.

SIGMA reports for Kosovo* are focused on civil service and administrative law, integrity, public expenditure management and control, public procurement, and policymaking and co-ordination. Decision-making process in the administration lacked transparency, impartiality and neutrality. The legality of decision-making was put at risk because of corruption allegations. Although the ethical legal framework was in place, with different pieces of legislation that prevent corruption and foster the integrity of public service, the perception of corruption remained very high in Kosovo even in 2015. Even though every year fine progress was witnessed the civil servants of Kosovo institutions remained vulnerable to political interference, corrupt practices, and nepotism. The Institute for Public Administration had limited capacity and resources, which affected the quality and amount of training provided. Capacity for monitoring and managing the PAR is still a problem in spite of the efforts that are being made. The complete implementation of strategies and action plans was challenged by limited human and budgetary resources, and the lack of professionalism and motivation on the part of the staff. Furthermore, the objectives set out in the strategies and action plans were considered unrealistic. One of the challenges in the implementation of the PAR strategies was their broad and fragmented scope.

In all European Commission's Progress Reports for Kosovo had been specified that the ensuring of the delivery of public services to all people in Kosovo and establishment a professional, accountable, accessible, representative public administration free from political interference is a key European Partnership priority. Even in the Stabilization Association Agreement, it is pointed out that the goal of cooperation and dialogue between Kosovo and EU is the development of a professional, efficient and accountable public administration. Kosovo was recommended to improve professionalism, accountability, efficiency, and effectiveness of its public administration at all levels, which is fundamental for a successful implementation of the necessary future reforms. Non-merit-based recruitment, even on 2016, continued to adversely affect effectiveness, efficiency and professional independence of public administration.

In the Government Annual Work Plan for 2017, the objectives of the Ministry of Public Administration were the deepening of public administration and civil service management reforms and increase of liability and accountability; PA modernization with the aim of further improvement of services provided to citizens - increasing of transparency and integrity; raising the quality of services 
through e-Government; Improvement and development of the physical infrastructure of government institutions in order to provide adequate physical conditions for their functioning; and the training of civil servants

The post-war period found Kosovo with great need for public administration and institutions, and at that time the objective was the creation of the institutions, more than their efficiency and work. This is the main reason of the stagnation of this sector. Moreover, Kosovo's public administration lies between a deficient institutional legacy and with flaws transferred by a failed system on one hand, and a political class that, in spite of the young people involved, is it focused more in personal ambition and interest, as well lacks vision for the state to strengthen its structures, in the other hand. The reforming process of institutions of Kosovo which had started while the institution building process was still running was constantly challenged by budget opportunities, capacity building, drafting legislation and its implementation. Even though good formulations and a good draft of the reform were put on paper the implementation of these reforms remained a challenge that didn't fully overcame.

The commitment of Kosovo's leadership only with reforms that sent Kosovo toward the European Integration first without being able to meet the needs of its own citizens means that the process has taken another direction which might be a dead end.

\section{REFERENCES}

[1] Wilson, W. T, "The Study of Administration", The Academy of Political Science, vol. 2, no. 2, pp. 197-222, 1887 https://doi.org/10.2307/2139277.

[2] Corson, J. J., \& Haris, J. P, Public Administration in Modern Society, New York: McGraw-Hill Book Company, 1963.

[3] Simon, H. A., Smithburg, D. W., \& Thompson, V. A, Public Administration, New Brunswick, New Jersey: Transaction Publishers, 1991.

[4] Bartholomew, P. C, Public Administration, New Jersey: Littlefield, Adams \& Co, 1972.

[5] United Nations Security Council, Report of the Secretary-General on the United Nations Interim Administration Mission in Kosovo (S/1999/779). Security Council, Distr.: General, 12 July 1999.

[6] Provisional Institutions of Self-Government of Kosovo (PISG)., \& United Nations Interim Administration Mission in Kosovo (UNMIK), Kosovo Public Administration Strategy: 2004 - 2006 Towards a professional, responsive and impartial public service, Prishtina: Ministry of Public Services, 2004.

[7] United Nations Security Council, Resolution 1244 (S/Res/1244), Security Council, Distr.: General, 10 June 1999.

[8] United Nations, Security Council, Report of the Secretary-General on the United Nations Interim Administration Mission in Kosovo, (S/2003/421), Security Council, Distr.: General, 14 April 2003.

[9] United Nations Security Council, Report of the Secretary-General on the United Nations Interim Administration in Kosovo, (S-2000-177), Security Council, Distr.: General, 13 March 2000.

[10] United Nations Security Council, Report of the Secretary-General on the United Nations Interim Administration in Kosovo, (S-2000-177), Security Council, Distr.: General, 3 March 2000.

[11] United Nations Security Council, Report of the Secretary-General on the United Nations Interim Administration in Kosovo, (S-2003-113), Security Council, Distr.: General, 29 January 2003.

[12] United Nations, Security Council, Report of the Secretary-General on the United Nations Interim Administration Mission in Kosovo, (S/2002/436), Security Council, Distr.: General, 22 April 2002.
[13] United Nations, Security Council, Letter dated 26 March 2007 from the Secretary-General addressed to the President of the Security Council, (S/2007/168), Security Council, Distr.: General, 26 March 2007.

[14] UNMIK, Regulation on the Kosovo Civil Service, (RE 2001-36), 22 December 2001. Retriwed form http://www.unmikonline.org/regulations/2001/RE\%202001-36.pdf

[15] Ministry of Public Administration, Action Plan for Public Administration in Kosovo 2009-2012, Prishtina: Ministry of Public Administration.

[16] Republic of Kosovo, Government, Public Administration Reform Strategy (2010-2013), Approved by Government decision no. 07/145. 7-8, 2010.

[17] Republic of Kosovo, Government, Strategy on Modernization of Public Administration 2015-2020, Prishtina: Ministry of Public Administration, 2015.

[18] Ministry of Public Administration, The Strategy for Training of Civil Servants 2016-2020, Prishtinë: Republic of Kosovo, Government, 2015.

[19] OECD/SIGMA, Baseline Measurement Report: The Principles of Public Administration Kosovo*, Paris, France: OECD/SIGMA, 2015.

[20] European Commission, Commission Communication on a Feasibility Study for a Stabilisation and Association Agreement between the European Union and Kosovo*, (SWD(2012) 339 final/2), Brussels: European Commission, 2012.

[21] European Commission, Kosovo* 2016 Report, (SWD(2016) 363 final), Brussels: European Commission, 2016.

[22] The Office of Prime Minister, Government Annual Work Plan Government Strategic Priorities, Prishtina: Government, 2017. 